\title{
SPECIES SHARE OF MOLINIO-ARRHENATHERETEA CLASS IN VEGETATION OF THE FOREST ARBORETUM IN ZIELONKA NEAR POZNAŃ AND IN ADJACENT TREESTANDS
}

\author{
Halina Ratyńska, Amelia Lewandowska, Barbara Waldon-Rudzionek, MaŁgorzata Mazur
}

H. Ratyńska, A. Lewandowska, B. Waldon-Rudzionek, M. Mazur, Departament of Botany, Institute of Environmental Biology, Kazimierz Wielki University, Ossolińskich 12, 85-093 Bydgoszcz, Poland, e-mail: halrat@wp.pl, bartczak@ukw.edu.pl,waldon@ukw.edu.pl,mazur@ukw.edu.pl

(Received: May 25, 2015. Accepted: August 6, 2015)

\begin{abstract}
Aвstract. Experimental-Research Unit - Forest Arboretum in Zielonka is located in the Puszcza Zielonka Landscape Park near Poznań and is bordering experimental forests of the Poznań University of Life Sciences. The aim of the studies was to identify the diversity of flora and vegetation of green areas in 13 landscape units, distinguished on the basis of the natural lie of the land, as well as forms and intensity of human impacts. 536 vascular plants species, including 82 of Molinio-Arrhenatheretea class and 102 plant communities with 13 of green areas therein were identified. Taxa and syntaxa of the class mentioned above are present in nearly all complexes of plant communities. The largest acreage of meadows and pastures belongs to the complex of green areas, where the presence of 57 species of Molinio-Arrhenatheretea class and seven associations were revealed. The lowest number of such indicators was found in aquatic and rush vegetation complex of water basins and in ruderal vegetation of build-up areas and roads, whereas their absence in watercourses vegetation complex. Characteristic species share of Molinia and fresh green areas is highly variable in analysed delimitations.
\end{abstract}

KeY WORDS: green areas, flora and vegetation, Forest Arboretum in Zielonka

\section{INTRODUCTION}

Experimental-Research Unit - Forest Arboretum in Zielonka was established in 1979. In has an area of 83 ha and is localized on the periphery of Zielonka within the Zielonka Forest Landscape Park near Poznań. A collection of over 800 taxa of arboraceous plants was made here. In Arboretum classes for students of the Poznan University of Life Sciences, primary and secondary school students within biology and environmental science are given. It is also a place of an active recreation and garden education not only for the inhabitants of Poznań. In the vicinity dominate timber forests: phytocoenoses of acidophilous oak forests and plantings, mainly of the pine.

In this area geobotanical recognitions have been carried out, focused mainly on forest issues (i.a.: Nowaczyk 1964, Danielewicz 1994, Danielewicz \& Strzeliński 1994a, b, Danielewicz et al. 1995, Rut-
KOWSKI et al. 2002, RATYŃSKA et al. 2011). Thermophilous groups (KLIMKO et al. 2006, RATYŃSKA et al. 2010a) and marsh-aquatic groups (STANIEWSKA-ZĄTEK 1977, Szwed et al. 2001, KucZyŃSKA-KIPPEN \& StefaNIAK 2003, MaciejeWsKa-RutKowsKa et al. 2004 and Przybylak 2007, 2008, 2009) were examined. There were also many floristic reports (URBAŃsKI 1930a, b, Nowaczyk 1959, 1960, GąbKa 2000, Przybylak 2006, Przybylak \& Śliwa 2007).

The aim of this article is to demonstrate variety of plant communities of Molinio-Arrhenatheretea class and share of this class species within spatial units distinguished inside Arboretum and in adjacent experimental forests.

\section{MATERIALS AND METHODS}

Basic materials of this paper were collected with participation of biology students of Kazimierz Wielki University in Bydgoszcz during scientific camps in 2003-2004 and supplemented in 2005 and 2012. 
Natural potential vegetation was defined. According to the methods proposed by Tüxen (1973) and Solon (1983) in the research area 13 spatial units of plant community complexes were delimitated. Homogenous habitat conditions, as well as human impact intensity constituted the distinction criteria. In each unit vascular plant flora and plant communities were noted. Their share was presented in Braun-Blanquet scale.

Furthermore, with generally adopted Braun-Blanquet method, 121 phytosociological relevés were performed, including eight within typical green area plant communities.

Plant nomenclature, taxonomic perspective, abundance and geographical-historical group spectrum in accordance with RUTKOWSKI (2004) and RATYŃSKA et al. (2010b). Life forms were adopted after JACKOWIAK (1990). Syntaxonomical point of view and evaluation of abundance and plant communities' threat were brought according to RATYŃSKA et al. (2010b). Protected habitat types were in accordance with Regulation of the Minister for the Environment from 30 October 2014 (OBwieszCZENIE... 2014). Economic value including the occupied space and productivity of green area plant communities was evaluated in a four-degree scale.

With reference to statistical analyses MVSP software was used (Kovach 2002): including for flora - Unweighted Pair Group Method with Arithmetic Mean (UPGMA), for plant communities - Principal Component Analysis (PCA).

\section{GENERAL DESCRIPTION OF THE AREA}

Arboretum and adjacent forests are located in morphologically varied area, which is a result of a postglacial region history. From a geographical point of view it is a western part of the Gniezno Lakeland. Moraine upland reaching an altitude of $100 \mathrm{~m}$ ASL is a glacial trough where the small river Trojanka flows. In the vicinity a highly overgrown lake Zielonka and within Arboretum area two ponds are located. Surrounding oak and pine-oak treestands are the experimental forests of the Poznań University of Life Sciences. The examined area is crossed by a road and network of forest dirt roads.

In regard to natural potential vegetation dominate acidophilous oak forest located in the highest parts of the moraine. Smaller areas, mainly in boggy parts of the Trojanka valley are covered by fertile alder carr forest and alder riparian forest. Transitional zones between these ecotopes, with a scarce area, are potential habitats for alder riparian forest and oak-linden-hornbeam forest. Natural vegetation of non-forest habitats - fens and aquatic vegetation has a small share (Fig. 1).

The area of Arboretum was formerly used agriculturally: in watercourse valley meadows were pre- sent and in upland - arable lands. On account of the predominance of poor soils, cultivations were ceased which contributed to a secondary development of forest areas - mainly Pinus sylvestris plantings. Pine spreads also spontaneously and enters the bare parts of grasslands. Do not mowed Molinia meadows have been overgrown by the alder. On edges of initial bog forests, bushes and meadows nitrophilous tall herbs were observed. In the river valley and on the edge of the pond numerous rush communities are observed. Strongly eutrophicated water basins are considerably overgrown. In the pond vicinity in Arboretum small delimitations of wet green areas and in slopes fresh meadows and grasslands, mainly psammophilous are present. Their acreage has decreased distinctly, they are not grazed, but only mowed with a various frequency. Ruderal tall herbs and trampling vegetation related mainly to road edges and build-up areas are not numerous.

\section{RESULTS}

Morphological variety translates into natural habitat diversity, which connected to human activity forms contributes to distinguishing of 13 delimitations of plant communities complexes in this area (Fig. 2).

Within them 536 vascular plant taxa were found (Table 1 ). Floristically the richest (216 species) was plant community complex accompanying a forest nursery. Slightly less species (201) were observed within green areas. The poorest delimitations are with aquatic and rush vegetation of a watercourse (14) and a pond (55).

Eighty-two species of Molinio-Arrhenatheretea were found in total (Fig. 3). Within this group 20 represent Molinio-Arrhenatheretea class, 26 flora of Molinia communities from Molinietalia (including 12 Calthion alliance), 21 fresh meadows (Arrhenatheretalia), and 18 pastures and tramplings (Trifolio repentis-Plantaginetalia majoris).

The most of edificators of Molinio-Arrhenatheretea (57) were found within complex of green areas and they have there the largest share. Rich in characteristic of this class are vegetation of segetal and ruderal forest nursery complex (39) and rush delimitation as well as transitional mire complex (37 species of each). They were not found in the watercourse.

Species of the largest ecological scale occurring in more than a half of the examined delimitations are Achillea millefolium, Arrhenatherum elatius, Carex hirta, Dactylis glomerata, Festuca rubra, Galium mollugo, Plantago major, Poa pratensis, Potentilla reptans, Prunella vulgaris, Ranunculus acris, R. repens, Taraxacum officinale, Trifolium repens and Veronica chamaedrys. Among them the most abundant are characteristic for fresh meadows -6 , then for pastures and tramplings -5 and all-meadow -4 . 
In the examined area, 102 plant communities were identified, mainly at association level (Table 1). Similarly, as in case of the flora, the majority of the groups (24), often with incompletely developed character were observed in the nursery forest. Also roadsides are characterised with a varied vegetation (19). The poorest are complexes dominated with acidophilous oak forest (2) and forest replacement communities with pine (5).

Thirteen plant communities, including nine of an association level belong to Molinio-Arrhenatheretea class (Table 2). Only three (Arrhenatheretum elatioris, Angelico-Cirsietum oleracei and Lolio perennis-Cynosuretum cristati) have a great and further three a significant economic importance.

The majority of the identified communities is not threatened. V cathegory (vulnerable) have: Arrhenatheretum elatioris, Angelico-Cirsietum oleracei and Scirpetum sylvatici, whereas Lolio perennis-Cynosuretum cristati belongs to group of indeterminate threat (I).
Syntaxon revealing expansion is Juncetum macri. Scirpetum sylvatici and Prunello-Plantaginetum constitute natural syntaxa. All the groups are common or frequent.

Most of Molinio-Arrhenatheretea class (7) communities were noted in complex of green areas and they occupy the largest area there. As many as four of these groups, in majority tramplings, were observed in the nursery forest. Three phytocoenoses were related to roadsides. A large share of fresh meadow phytocoenoses was noted in grassland complexes as well as tall-grass and ruderal vegetation of roadsides.

Results of agglomerative hierarchical classification (UPGMA) executed for full flora of the analysed area allow to distinguish groups of plant community complexes, which go mainly with moisture gradient (Fig. 4). Flora of green areas differs distinctly from other, drier delimitations and refers to a great extent to moist ecosystems. Mutual relations between units associated with forests (pine planting vegetation

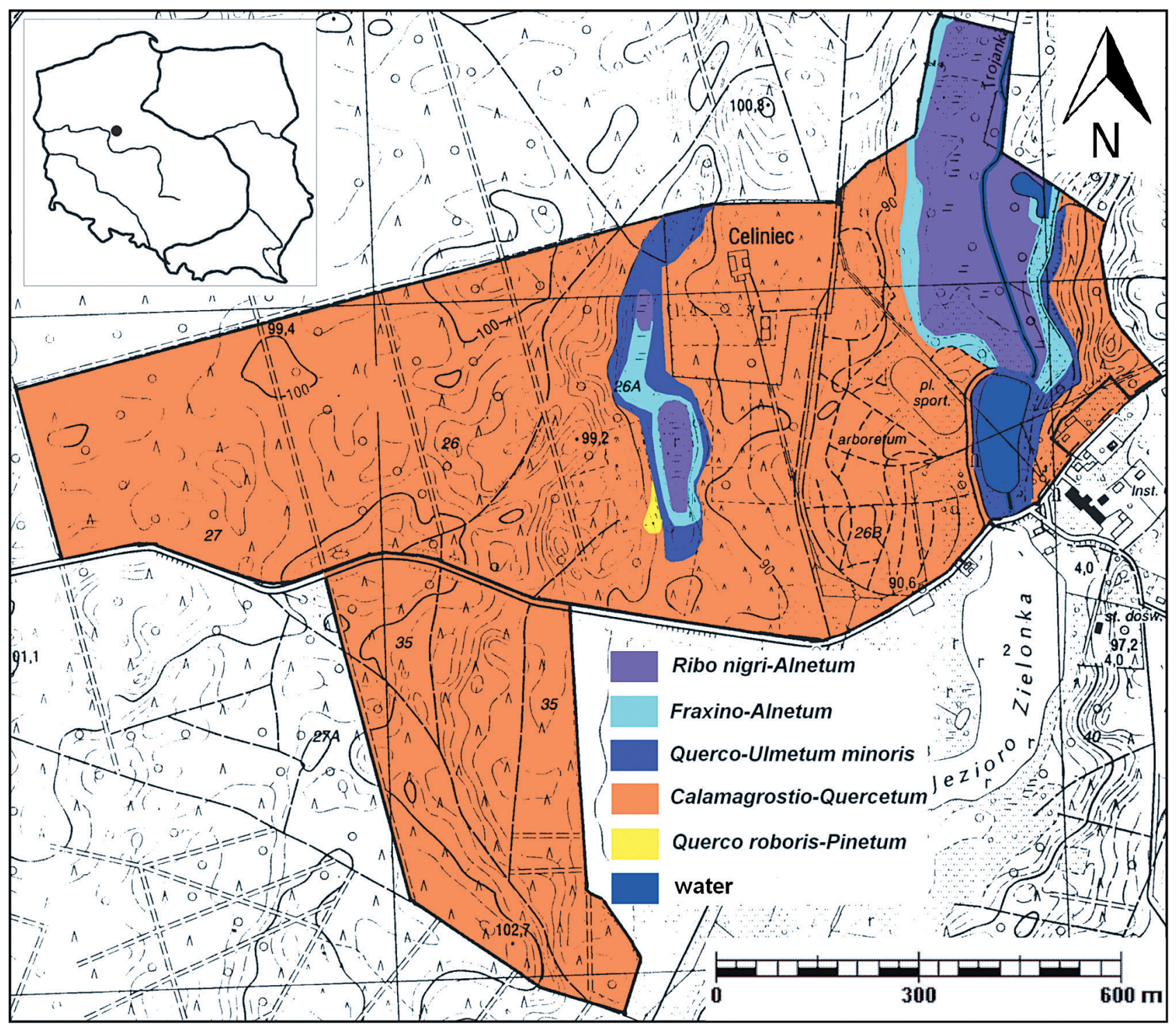

Fig. 1. Natural potential vegetation in the study area 


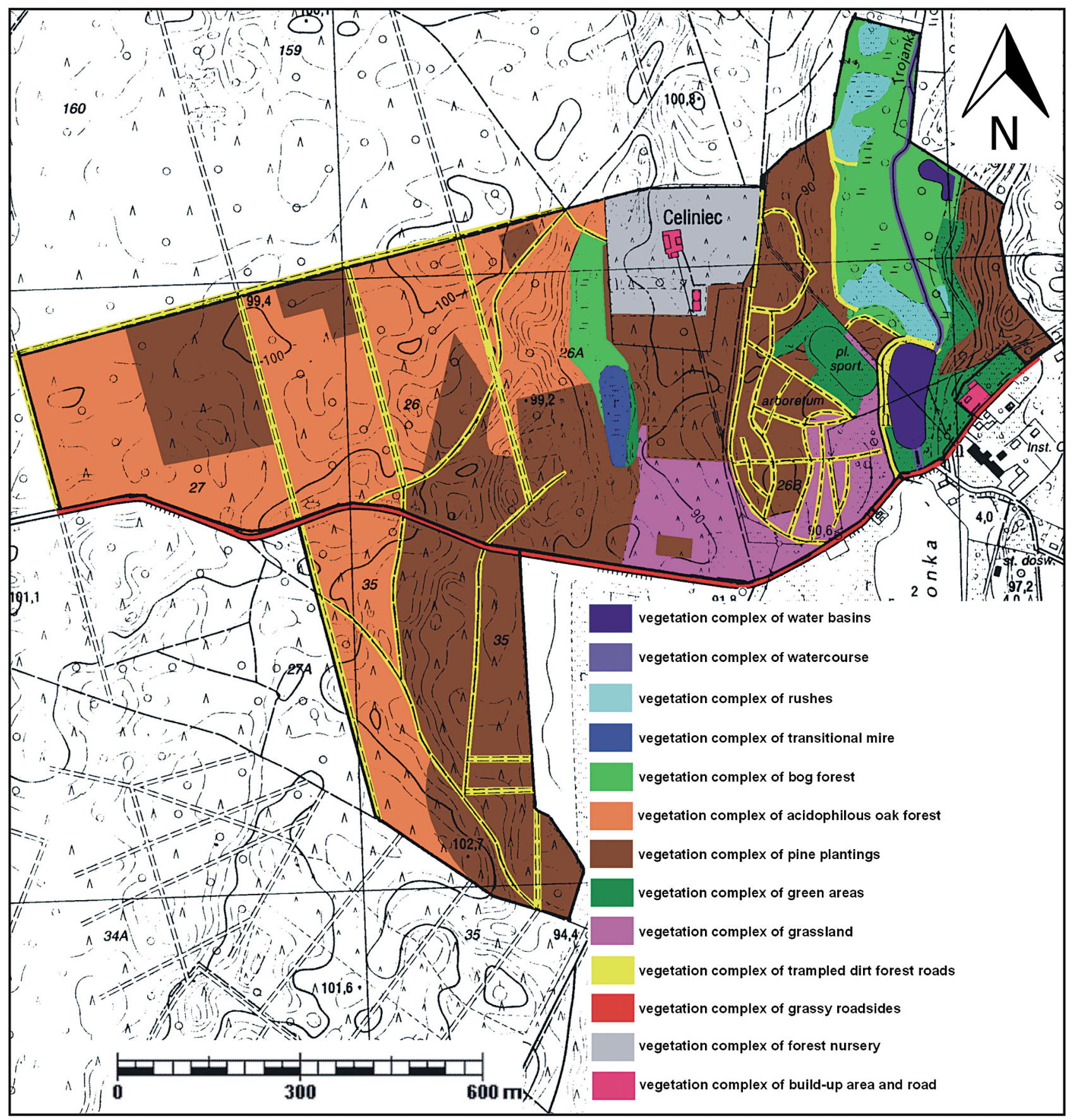

Fig. 2. Real vegetation in the study area (plant community complexes)

Table 1. Share of vascular plants and plant communities in the distinguished landscape units

\begin{tabular}{|c|c|c|c|c|c|c|c|c|c|c|c|c|c|c|}
\hline Complex number & 1 & 2 & 3 & 4 & 5 & 6 & 7 & 8 & 9 & 10 & 11 & 12 & 13 & \\
\hline Vegetation complex of & 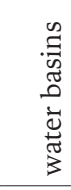 & 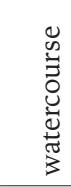 & 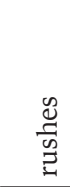 & 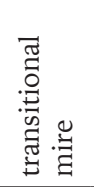 & $\begin{array}{l}\breve{0} \\
\stackrel{0}{0} \\
0 \\
0 \\
0\end{array}$ & 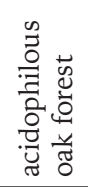 & 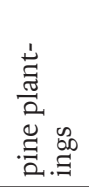 & 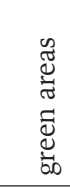 & 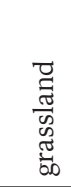 & 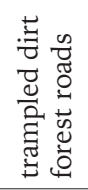 & 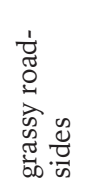 & 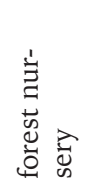 & 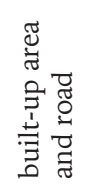 & 胥 \\
\hline Number of species & 55 & 14 & 132 & 133 & 157 & 126 & 180 & 201 & 181 & 90 & 159 & 216 & 104 & 536 \\
\hline $\begin{array}{l}\text { Number of species from Moli- } \\
\text { nio-Arrhenatheretea }\end{array}$ & 12 & 0 & 37 & 37 & 34 & 15 & 27 & 57 & 34 & 23 & 29 & 39 & 12 & 82 \\
\hline Number of communities & 16 & 6 & 10 & 16 & 10 & 2 & 5 & 12 & 17 & 8 & 19 & 24 & 17 & 102 \\
\hline $\begin{array}{l}\text { Number of communities from } \\
\text { Molinio-Arrhenatheretea }\end{array}$ & 0 & 0 & 0 & 2 & 0 & 0 & 0 & 7 & 1 & 2 & 3 & 4 & 2 & 13 \\
\hline
\end{tabular}




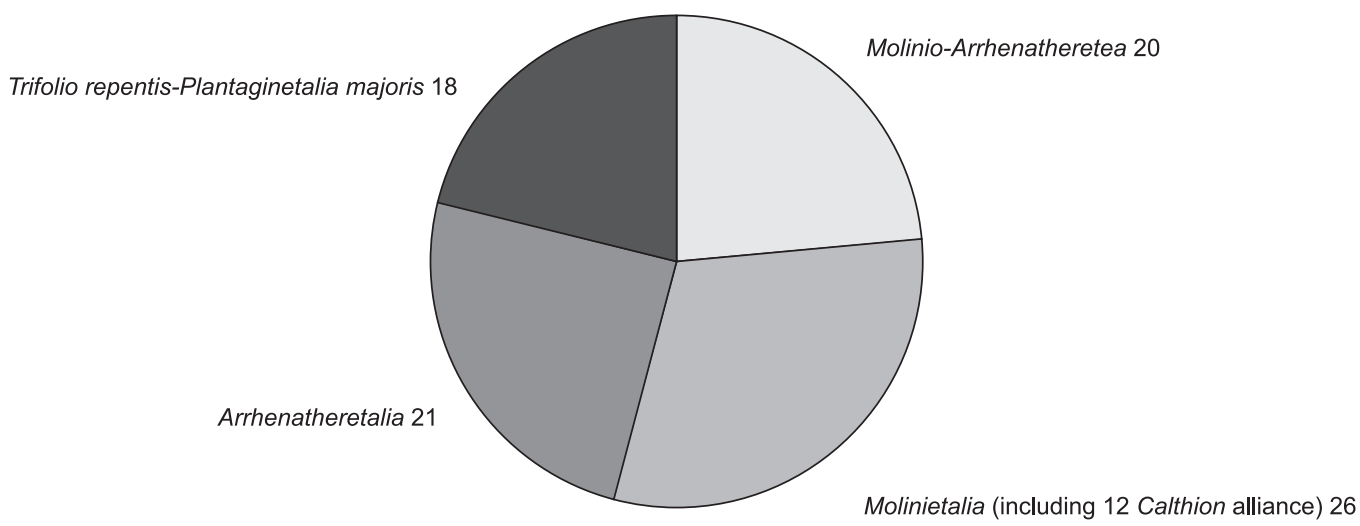

Fig. 3. Spectrum of species share of Molinio-Arrhenatheretea class

complexes, acidophilous oak forest vegetation complex and forest track trampling vegetation complex) and strongly transformed units (segetal and ruderal vegetation complexes of nursery forest and ruderal vegetation of build-up area and road) are noticeable.

Axis proper values of diagram resulted from principal component analysis (PCA) for the plant communities indicate that gradient represented by the first axis distinctly diversifies their occurrence and explains $22.45 \%$ of their variation while the second axis $-13.63 \%$ (Fig. 5). Critical factors influencing the sample distribution comprise of moisture degree and anthropopressure intensity. The chart shows communities which have the strongest impact on differentiation of respective delimitations.

\section{DISCUSSION}

Despite a small area of the Arboretum and adjacent experimental forests of the Poznan University of Life Sciences, plant cover is very rich: phytocoenoses of 102 plant communities and 536 vascular plant taxa were found. It follows both from natural factors and diverse forms of anthropopressure.

Table 2. Systematic list and characteristics of plant communities of Molinio-Arrhenatheretea class

\begin{tabular}{|c|c|c|c|c|c|}
\hline Syntaxon & $\begin{array}{l}\text { Categories } \\
\text { of threat }\end{array}$ & Syngenesis & Frequency & $\begin{array}{l}\text { Regula- } \\
\text { tion ME }\end{array}$ & $\begin{array}{l}\text { Economic } \\
\text { significance }\end{array}$ \\
\hline \multicolumn{6}{|l|}{ Cl. Molinio-Arrhenatheretea R. Tx. 1937 em. 1970} \\
\hline 1. Holcus lanatus community (Syn.: Holcetum lanati Issler 1936) & - & SN & $\mathrm{P}$ & & $* *$ \\
\hline $\begin{array}{l}\text { 2. Anthoxanthum odoratum community (Not: Anthoxantho odora- } \\
\text { ti-Agrostietum tenuis Sillinger 1933) }\end{array}$ & - & SN & $\mathrm{C}$ & & * \\
\hline $\begin{array}{l}\text { 3. Juncus effusus community (frgm. Epilobio-Juncetum effusi Oberd. } \\
\text { 1957?) }\end{array}$ & - & SN & $\mathrm{C}$ & & * \\
\hline 4. Carex hirta community & - & SN & $\mathrm{C}$ & & - \\
\hline \multicolumn{6}{|l|}{ O. Molinietalia W. Koch 1926} \\
\hline \multicolumn{6}{|l|}{ All. Calthion R. Tx. 1937} \\
\hline 5. Scirpetum sylvatici Ralski 1931 & V & $\mathrm{N}$ & $\mathrm{C}$ & & - \\
\hline 6. Angelico-Cirsietum oleracei R. Tx. 1937 em. 1947 & $\mathrm{~V}$ & SN & $\mathrm{C}$ & & $* * *$ \\
\hline 7. Stellario palustris-Deschampsietum cespitosae Freitag 1957 & - & $\mathrm{SN}$ & $\mathrm{P}$ & & ** \\
\hline \multicolumn{6}{|l|}{ O. Arrhenatheretalia Pawłowski 1928} \\
\hline \multicolumn{6}{|l|}{ All. Arrhenatherion elatioris W. Koch 1926} \\
\hline 8. Arrhenatheretum elatioris Braun 1915 & $\mathrm{~V}$ & SN & $\mathrm{P}$ & 6510 & $* * *$ \\
\hline \multicolumn{6}{|l|}{$\begin{array}{l}\text { O. Trifolio repentis-Plantaginetalia majoris (R. Tx. et Preising in R. Tx. } \\
1950 \text { em. Sissingh 1969) Brzeg } 1991 \text { ex Balcerkiewicz et Pawlak } 2001\end{array}$} \\
\hline \multicolumn{6}{|l|}{ All. Cynosurion R. Tx. 1947} \\
\hline 9. Lolio perennis-Cynosuretum cristati R. Tx. 1937 & I & SN & $\mathrm{C}$ & & $* * *$ \\
\hline 10. Lolio-Plantaginetum Beger 1932 em. Sissingh 1969 & - & SN & $\mathrm{P}$ & & - \\
\hline 11. Prunello-Plantaginetum Faliński 1961 ex 1963 & I & NA & $\mathrm{C}$ & & - \\
\hline 12. Juncetum macri (Diemont et al. 1940) R. Tx. 1950 & $\mathrm{O}$ & $\mathrm{X}$ & $\mathrm{C}$ & & - \\
\hline \multicolumn{6}{|l|}{ All. Potentillion anserinae R. Tx. 1947} \\
\hline 13. Ranunculo repentis-Alopecuretum geniculati R. Tx. 1937 em. 1950 & - & SN & $\mathrm{C}$ & & ** \\
\hline
\end{tabular}

Explanations: Categories of threat: $\mathrm{V}$ - vulnerable, I - communities of indeterminate threat; - - not threatened; $\mathrm{O}$ - revealing expansion. Syngenesis: N - natural community without distinct dynamic tendencies; NA - natural auxochoric com.; SN - semi-natural com.; X xenospontaneous com.

Frequency: P - common; C - frequent. Regulation ME - Regulation of the Minister for the Environment from 30 October 2014.

Economic significance: - - lack; ${ }^{*}$ - marginal; ${ }^{* *}$ - significant; ${ }^{* *}$ - very large. 


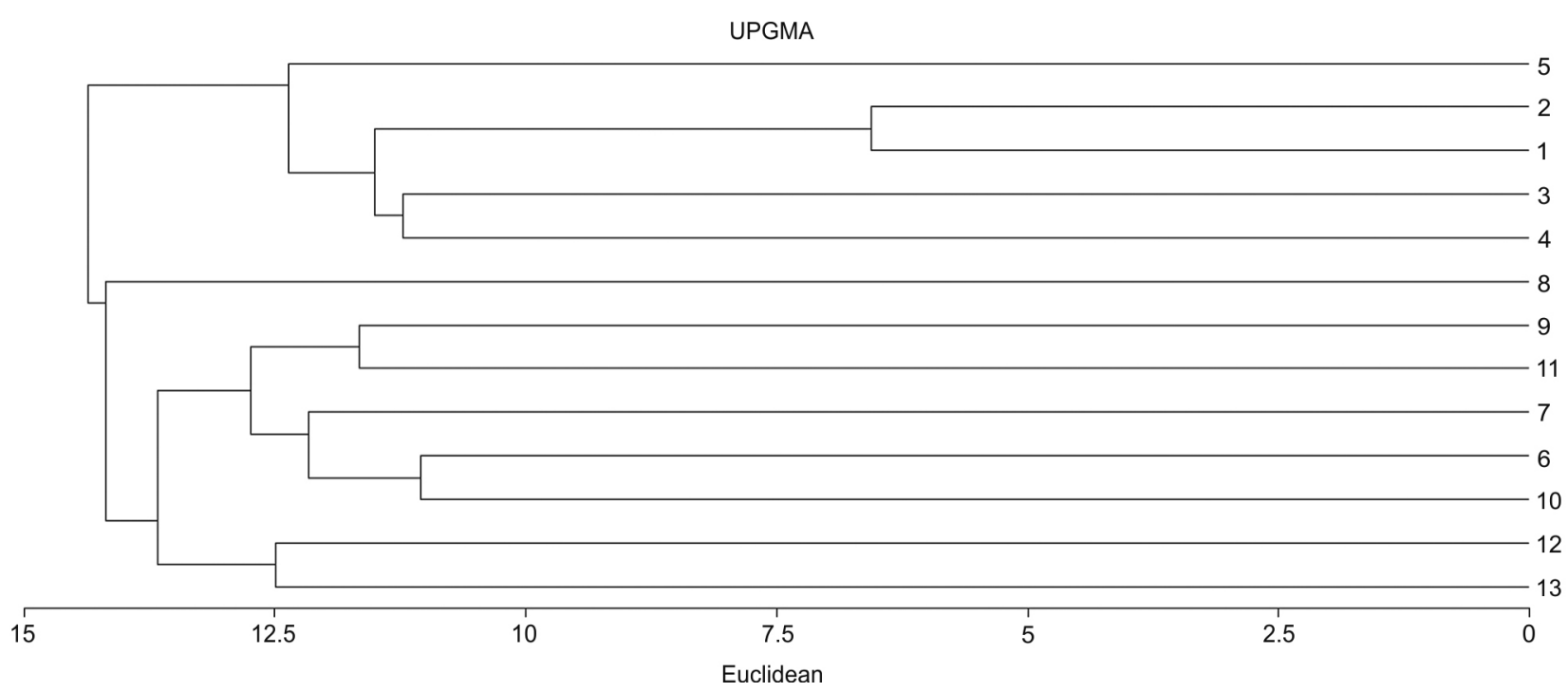

Fig. 4. Results of agglomerative hierarchical classification for flora - UPGMA (MVSP)

Numbers of vegetation complexes - see Table 1.

On account of predominance of acidophilous habitat of acidophilous oak forest and development plan, vegetation of green areas in the examined area is barely represented. Thirteen groups were identified, which comprised about $29 \%$ of all groups in the lowlands and the uplands (RATYŃSKA et al. 2010b). According to RATYŃSKA (2003) meadow and pastural associations, especially moist are the most abundant on habitats of alder riparian forests and elm-ash forests. Some of the green area communities (fresh meadows and

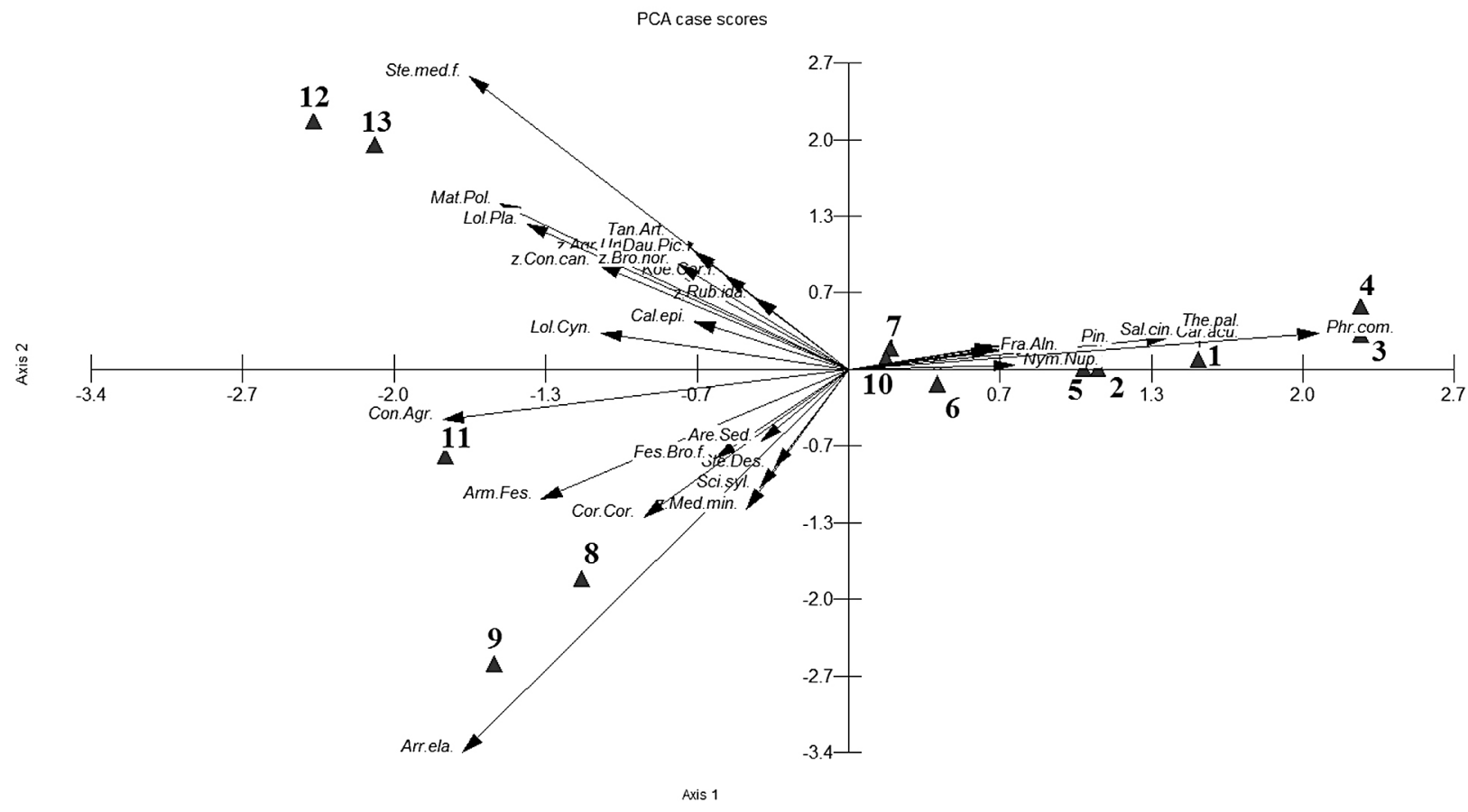

Vector scalina: 6.46

Fig. 5. Ordination diagram for the plant communities - Principal Components Analysis - PCA (MVSP). Short vectors have been removed

Numbers of vegetation complexes - see Table 1.

Explanations: Are.Sed. - Arenario-Sedetum acris, Arm.Fes. - Armerio elongatae-Festucetum ovinae, Arr.ela. - Arrhenatheretum elatioris, Cal.epi. Calamagrostietum epigeji, Car.acu. - Caricetum acutiformis, Con.Agr. - Convolvulo arvensis-Agropyretum repentis, Cor.Cor. - Corniculario-Corynephoretum, Dau.Pic. - Dauco-Picridetum, Fes.Bro.f. - phytocoenosis of Festuco-Brometea, Fra.Aln. - Fraxino-Alnetum, Koe.Cor.f. - phytocoenosis of Koelerio-Corynephoretea, Lol.Cyn. - Lolio-Cynosuretum, Lol.Pla. - Lolio-Plantaginetum, Mat.Pol. - Matricario-Polygonetum arenastri, n.Pin.syl. plantings of Pinus sylvestris, Nym.Nup. - Nymphaeo albae-Nupharetum luteae, Phr.com. - Phragmitetum communis, Rub.ida. - Rubetum idaei, Sal.cin. - Salicetum cinereae, Sci.syl. - Scirpetum sylvatici, Ste.med.f. - phytocoenosis of Stellarietea mediae, Ste.Des. - Stellario-Deschampsietum cespitosae, Tan.Art. - Tanaceto-Artemisietum, The.Phr. - Thelypteridii-Phragmitetum, z.Agr.Urt. - community of Agropyron repens-Urtica dioica, z.Bro.hor. community of Bromus hordaceus, z.Med.min. - community of Medicago minima. 
pastures) are strongly related with biotope of potential oak-hornbeam forest. Extreme habitats: coniferous forests and alder carr forests are nearly deprived of meadow and pastural vegetation.

Characteristic species of Molinio-Arrhenatheretea class are present in all delimitations except for watercourse. Predominance of dry habitats causes in the analysed complexes spreading the taxa of the largest ecological scale, mainly fresh meadow edificators (see also KuCHARsKi 1999). Meadow plants' migration process from degenerated, as a result of pratotechnical measures on green areas, to replacement communities was mentioned by CHMIEL (1995), attention was paid also to this phenomenon by Szwed et al. (1999), RATYŃSKa (2003) and StęPIEŃ (2009). Quoted authors put stress, among others, on a distinct share of grassy vegetation in roadsides and railsides, especially Arrhenatheretum elatioris phytocoenoses therein, thereby significance of sides of routes for preservation of meadow species population. Also from other regions of Europe occurrence data of numerous green areas' species along roads were given (i.a.: Melman \& VerkaAr 1991, Persson 1995, JANTUNEN et al. 2007). Compulsory mowing causes preferring and development of herb communities, especially of fresh meadows. Well then, in a way as it were incidental, sides of routes are becoming refugia for plants and their groups disappearing from intensively managed green areas.

Arrhenatheretum elatioris belongs to the most common green area community both in Poland (KUCHARSKI \& MichalsKa-Hejduk 1994, ŻYsZKowsKa 2007, KrYsZAK et al. 2012), as well as in central Europe (DiersCHKE 1995, Duchoslav 1997, Kojić et al. 2005, Rozbrojová et al. 2010, VALEV et al. 2011). It is related with a large ecological scale of comprised species. In examined area it is reflected in the presence of association phytocoenoses not only within complexes of green areas but also grasslands and roadsides.

Worthy noticing is the fact that within green areas fresh meadows are the most abundant floristically not only within our country (LENGYEL et al. 2012).

\section{CONCLUSIONS}

In the Arboretum and adjacent forest complexes, meadows and pastures do not occupy bigger area and their acreage is not decreasing.

Green area species have a large ecological scale and they are present in all delimitations except for watercourse. Within them taxa of Molinia meadows are distinguished with a smaller ecological scale.

Plant communities of Molinio-Arrhenatheretea are characterised with a smaller ecological scale rather than species of this class and they were noted only in 7 out of 13 examined delimitations.

Outside complex of green areas bigger areas of meadow communities are related with grasslands and roadsides and to some extent within such areas protection of meadow vegetation can be implemented.

As in the area of nearly whole country, in order to maintain the vegetation of green areas active protection is needed, consisting in limiting the succession: regular mowing, and grazing. In the Arboretum mowing is performed by tree plantings care.

\section{ACKNOWLEDGMENT}

We would like to thank Iwona Łazowy-Szczepanowska for linguistic verification of the manuscript.

\section{REFERENCES}

Chmiel J. (1995): Ostoje rzadkich i zagrożonych roślin naczyniowych w krajobrazie rolniczym Pojezierza Gnieźnieńskiego. In: W. Żukowski, B. Jackowiak (eds). Ginące i zagrożone rośliny naczyniowe Pomorza Zachodniego i Wielkopolski. Prace Zakładu Taksonomii Roślin UAM 3. Bogucki Wydawnictwo Naukowe, Poznań: 127-136.

DANielewicz W. (1994): Rozsiedlenie czeremchy amerykańskiej Prunus serotina Ehrh. na terenie Nadleśnictwa Doświadczalnego Zielonka. Prace Komisji Nauk Rolniczych i Komisji Nauk Leśnych PTPN 78: 35-42.

Danielewicz W., Malíśi T., Zatorski J. (1995): Kulturowe i przyrodnicze znaczenie zadrzewień wzdłuż historycznych traktów śródleśnych na terenie Parku Krajobrazowego „Puszcza Zielonka”. Przegląd Przyrodniczy 6(3-4): 159-170.

DANielewicz W., Strzeliński P. (1994a): Inwentaryzacja dendrologiczna w południowej części Puszczy Zielonki koło Poznania. Przegląd Przyrodniczy 5(3-4): 191-200.

Danielewicz W., StrZelí́ski P. (1994b): Skład gatunkowy dendroflory ukształtowanej pod wpływem gospodarki leśnej na siedliskach boru mieszanego świeżego i lasu mieszanego świeżego w Nadleśnictwie Doświadczalnym Zielonka. Prace Komisji Nauk Rolniczych i Komisji Nauk Leśnych PTPN 78: 43-51.

DierschKe H. (1995): Syntaxonomical survey of Molinio-Arrhenatheretea in Central Europe. Colloques Phytosociologiques 23: 387-399.

Duchoslav M. (1997): The present state of meadow vegetation (Molinio-Arrhenatheretea) in the Morava river floodplain (Hornomoravský úval area). Zprávy České. Botanické Společnosti 1, Materiály 15: 131-176.

GĄBKA M. (2000): Osobliwości florystyczne rezerwatów „Jezioro Czarne” i „Jezioro Pławno” w Parku Krajobrazowym „Puszcza Zielonka” koło Poznania. Badania Fizjograficzne nad Polską Zachodnią 49: 189-193. 
JACKOWIAK B. (1990): Antropogeniczne przemiany flory roślin naczyniowych Poznania. Ser. Biologia 42. Wyd. Nauk. UAM, Poznań.

Jantunen J., Saarinen K., Valtonen A., Saarino S. (2007): Flowering and seed production success along roads with different mowing regimes. Applied Vegetation Sciences 10(2): 285-292.

Klimko M., Górski P., Czekalski M., Czarna A. (2006): Anthemis tinctoria L. (Asteraceae) in the Zielonka Forest (the Wielkopolska region, Poland). Roczniki Akademii Rolniczej w Poznaniu 378, Botanika-Steciana 10: 109-120.

Kojić M., Mrfat-Vukelić S., Dordević-Milošević S. (2005): Basic phytocenological and economical characteristics of natural meadows and pastures of Serbia. Biotechnology in Animal Husbandry 21 (5-6): 187-191.

Kovach W.L. (2002): Multivariate Statistical Package. Version 3.1. Pentraeth, Wales U.K.

Kryszak A., KlarzyŃSKa A., KrysZak J., Strychalska A., MAĆKOWIAK Ł. (2012): Influence of variability of ryegrass meadow soil conditions on their natural and utilization values. Notulae Botanicae Horti Agrobotanici Cluj-Napoca 40(1): 163-169.

KUCHARSKI L. (1999): Szata roślinna łąk Polski Środkowej i jej zmiany w XX stuleciu. Wyd. Uniwersytetu Łódzkiego, Łódź.

Kucharski L., Michalska-Hejduk D. (1994): Przegląd zespołów łąkowych z klasy Molinio-Arrhenatheretea stwierdzonych w Polsce. Wiadomości Botaniczne 38(1-2): 95-104.

KuCZyŃSKa-KipPen N., StefaniaK K. (2003): Struktura przestrzenna letnich zbiorowisk fito- i zooplanktonu na tle różnych zbiorowisk hydromakrofitów jeziora Pławno. Biuletyn Parków Krajobrazowych Wielkopolski 9(11): 112-127.

Lengyel A., Purger D., Csiky J. (2012): Classification of mesic grasslands and their transitions of South Transdanubia (Hungary). Acta Botanica Croatica 71(1): 31-50.

MaciejeWSKa-RutKowska I., ŁopatKa I., RUtKowski P. (2004): Stan aktualny szaty roślinnej na przesuszonych siedliskach bagiennych w okolicy jeziora Kamińsko (Park Krajobrazowy Puszcza Zielonka). Biuletyn Parków Krajobrazowych Wielkopolski 10(12): 118-134.

Melman P.J.M., VerkaAR H.J. (1991): Layout and management of herbaceous vegetation in road verges. In: D. van Bohemen, D.A.G. Buizer, A. Little (eds). Nature engineering and civil engineering works. Ministry of Transport, Public Works and Water Management, Wageningen: 62-78.

NowaczyK Cz. (1959): Mszaki Doświadczalnego Nadleśnictwa Zielonka pod Poznaniem. Roczniki WSR Poznań 7: 137-157.

NowACzyK Cz. (1960): Rzadsze rośliny naczyniowe znalezione w Doświadczalnym Nadleśnictwie
Zielonka pod Poznaniem. Badania Fizjograficzne nad Polską Zachodnią 6: 285-288.

NowaczyK Cz. (1964): Zespoły leśne Doświadczalnego Nadleśnictwa Zielonka pod Poznaniem. Prace Komisji Nauk Rolniczych i Komisji Nauk Leśnych PTPN 17(2): 213-269.

OBWIESZCZENIE Ministra Środowiska z dn. 30 października 2014 r. w sprawie ogłoszenia jednolitego tekstu rozporządzenia Ministra Środowiska w sprawie siedlisk przyrodniczych oraz gatunków będących przedmiotem zainteresowania Wspólnoty, a także kryteriów wyboru obszarów kwalifikujących się do uznania lub wyznaczenia jako obszary Natura 2000. Dz.U. 2014, poz. 1713.

Persson T.S. (1995): Management of roadside verges: vegetation changes and species diversity. Swedish University of Agricultural Sciences Department of Ecology and Environmental Research Section for Conservation Botany. Uppsala, Report 82.

Przybylak M. (2006): Nowe gatunki roślin w Parku Krajobrazowym Puszcza Zielonka. Biuletyn Parków Krajobrazowych Wielkopolski 12(14): 126-130 .

Przybylak M. (2007): Kolejne stanowisko turzycy bagiennej Carex limosa L. w Parku Krajobrazowym Puszcza Zielonka. Biuletyn Parków Krajobrazowych Wielkopolski 13(15): 130-131.

Przybylak M. (2008): Flora i roślinność siedlisk bagienno-wodnych $\mathrm{w}$ otoczeniu Jeziora Czarnego w Parku Krajobrazowym Puszcza Zielonka. Biuletyn Parków Krajobrazowych Wielkopolski 14(16): 110-116.

Przybylak M. (2009): Monitoring kukułki krwistej Dactylorhiza incarnata (L.) Soó nad jeziorem Zielonka w Parku Krajobrazowym Puszcza Zielonka. Biuletyn Parków Krajobrazowych Wielkopolski 15(17): 52-57.

Przybylak M., Śliwa D. (2007): Rośliny naczyniowe grodziska Głęboczek w Parku Krajobrazowym „Puszcza Zielonka”. Biuletyn Parków Krajobrazowych Wielkopolski 13(15): 106-110.

RATYŃSKA H. (2003): Szata roślinna jako wyraz antropogenicznych przekształceń krajobrazu na przykładzie zlewni rzeki Głównej (środkowa Wielkopolska). Wyd. Akademii Bydgoskiej im. Kazimierza Wielkiego, Bydgoszcz.

RatyŃska H., Grodzki M., Waldon B., Wachowiak E. (2011): Introduction of alien tree species and its influence on floristical composition and vegetation structure of acidophilous oak forests: the experimental plots in the Zielonka Forest. Acta Universitatis Lodziensis, Folia Biologica et Oecologica 7: 177-190.

RatyŃska H., Lewandowska A., Mazur M., Waldon B. (2010a): Zróżnicowanie roślinności murawowej i termofilnych okrajków w Arboretum Leśnym w Zielonce koło Poznania. In: H. Ratyńska, B. Waldon (eds). Ciepłolubne murawy w Polsce, 
stan zachowania i perspektywy ochrony. Wyd. Uniwersytetu Kazimierza Wielkiego, Bydgoszcz: 290-300.

RatyŃska H., Wojterska M., Brzeg A. (2010b): Multimedialna encyklopedia zbiorowisk roślinnych Polski. NFOŚiGW, UKW, IETI, Bydgoszcz.

Rozbrojová Z., HÁjek M., HÁjEK O. (2010): Vegetation diversity of mesic meadows and pastures in the West Carpathians. Preslia 82: 307-332.

Rutkowski L. (2004): Klucz do oznaczania roślin naczyniowych Polski niżowej. Wyd. Nauk. PWN, Warszawa.

RutKowsKi P., MACIEJEWSKA-RUTKOWSKA I., ŁABĘDZKA M. (2002): Właściwy dobór składu gatunkowego drzewostanów jako jeden ze sposobów walki z czeremchą amerykańską (Prunus serotina Ehrh.) na przykładzie Nadleśnictwa Doświadczalnego Zielonka. Acta Scientiarum Polonorum 1(2): 59-73 .

Solon J. (1983): The local complex of phytocenoses and the vegetation landscape - fundamental units of the spatial organization of the vegetation above the phytocenose level. Acta Botanica Hungaricae 29(1-4): 377-384.

StANIEWSKA-ZĄTEK W. (1977): Zespół Cladietum marisci All. 1922 w Wielkopolsce. Badania Fizjograficzne nad Polską Zachodnią 30: 69-82.

STĘPIEŃ E. (2009): Changes of meadow flora species in area of Cedyński Landscape Park. Polish Journal of Environmental Studies 18(6): 1211-1215.

Szwed W., Maciejewska-RutKowska I., Szafrański F. (2001): Szata roślinna projektowanego rezerwatu „Jezioro Bolechowskie” (Park Krajobrazowy
„Puszcza Zielonka”). Biuletyn Parków Krajobrazowych Wielkopolski 7(9): 71-96.

Szwed W., Ratyńska H., Danielewicz W., Mizgajski A. (1999): Przyrodnicze podstawy kształtowania marginesów ekologicznych w Wielkopolsce. Katedra Botaniki Leśnej AR im. A. Cieszkowskiego, Poznań.

Tüxen R. (1973): Vorschläge zur Aufnahme von Gesellschaftskomplexen in potentiell natürlichen Vegetationsgebieten. Acta Botanica Academiae Scientiarum Hungaricae 19(1-4): 379-384.

URBAŃSKI J. (1930a): Rezultaty wycieczek florystycznych po Wielkopolsce wraz z projektami ochrony stanowisk rzadkich roślin. Wydawnictwo Okręgowego Komitetu Ochrony Przyrody na Wielkopolskę i Pomorze 1: 37-46.

Urbański J. (1930b): Jezioro Czarne w lasach Nadleśnictwa Zielonka. Wydawnictwo Okręgowego Komitetu Ochrony Przyrody na Wielkopolskę i Pomorze 2: 46-48.

Valev N., Apostolova I., Rozbrojová Z. (2011): Alliance Arrhenatherion elatioris in West Bulgaria. Phytologia Balcanica 17(1): 67-78.

ŻyszKowsKa M. (2007): Zbiorowiska z rzędu Arrhenatheretalia jako wskaźnik warunków siedliskowych w dolinie Bystrzycy Dusznickiej. Woda-Środowisko-Obszary Wiejskie 7(2b): 205-218.

For citation: RATYŃSKA H., LEWANDOWSKA A., WALdon-Rudzionek B., Mazur M. (2015): Species share of Molinio-Arrhenatheretea class in vegetation of the Forest Arboretum in Zielonka near Poznań and in adjacent treestands. Steciana 19(4): 245253. doi: 10.12657/steciana.019.025 